\title{
TRACE METALS IN SELECTED FISH SPECIES FROM LAKES AWASSA AND ZIWAY, ETHIOPIA
}

\author{
Abayneh Ataro, Taddese Wondimu * and B.S. Chandravanshi \\ Department of Chemistry, Faculty of Science, Addis Ababa University, PO Box 1176 \\ Addis Ababa, Ethiopia. E-mail: tadese@chem.aau.edu.et
}

\begin{abstract}
Samples of two fish species (Tilapia Oreochromis niloticus and Catfish Clarias gariepinus) were collected from six sampling stations in Lakes Awassa and Ziway, Ethiopia. The edible portion was separated and placed in a freeze-drying unit until constant mass was obtained. The calculated moisture content of the two fish species obtained from six sites in the two lakes varied from $79.3 \%-82.5 \%$. An optimal procedure for mineralizing $2.0 \mathrm{~g}$ dried and powdered fish muscle required 7.0 hours and consumed $8.0 \mathrm{~mL}$ of $70 \% \mathrm{HNO}_{3}, 2.0 \mathrm{~mL}$ of $98 \% \mathrm{H}_{2} \mathrm{SO}_{4}$ and $10 \mathrm{~mL}$ of $35 \% \mathrm{H}_{2} \mathrm{O}_{2}$ under reflux. The accuracy of the optimal procedure was checked by digesting a mixture of standard solutions or spiked fish samples and subsequently determining percent recovery. Recoveries varied from $98.5 \%-123 \%$ in a mixture of standard solutions and from $92.5 \%-120 \%$ in spiked fish samples. Trace metal concentrations in the two fish species were measured by flame atomic absorption spectrometer employing an external calibration graph. Concentrations of trace elements in the fishes ranged ( $\mu$ g element/g dry mass): $\mathrm{Zn}$ 23.04-30.92; Fe 19.25-59.75; Cu 1.03-2.78; Mn 1.54-4.46; $\mathrm{Cd}<0.24 ; \mathrm{Pb}<1.66 ; \mathrm{Ni}<0.99$; and $\mathrm{Co}<0.71$. The maximum levels of trace metals found in edible portion of fishes were far below the thresholds. Hence, without regard to bioavailability, O. niloticus and C. gariepinus may be considered safe for human consumption relative to the analyzed elements.
\end{abstract}

\section{Key words/phrases: Bioindicators of lake pollution, Clarias gariepinus, Oreochromis niloticus, trace metals}

\section{INTRODUCTION}

Land degradation and growing trends in industrialization in Ethiopia have raised concerns about pollution of water bodies (in particular of lakes). However, lack of information hinders provision of comprehensive historical background of lake water pollution. The few scientific investigations carried out on Ethiopian lakes show the initiation of interest in the studies of lake water degradation. Talling and Talling (1965) measured concentrations of iron in Lakes Ziway, Langano, Abaya, Shala, Abijata and Methara. Baumann et al. (1975) recorded the concentrations of three heavy metals (copper, zinc and lead) among other elements, in Lakes Langano, Abijata, Shala and Chitu, and the study of Lake Abaya by Klein (1977) was primarily concerned with trace metals and their possible involvement in non-parasitic elephantiasis.

Recently the work by Telford (1998) indicated the presence of many trace metals in Lake Awassa. More recently Tamiru Alemayehu (2000) reported concentrations of some trace metals in Lake Langano, Edu Geyser, Oitu spring, Lake Shalla,
Eastern Shalla spring, Wonji Bulbula spring, Gergedi spring and Awash River (at Wonji). Despite these findings in lake waters, hot springs and rivers, there has been paucity of literature on the trace metal accumulation by fish. This information is desirable because fish resources are important bioindicators of pollution.

Fishes in freshwater environments near urban and industrial locations are often subjected to pollutants due to run-off and in most cases deliberate discharges (Gbem et al., 2001). Exposure of fish to water contaminated with trace metals can result in a significant accumulation of trace metals in their flesh (Jerzy, 1995; Farrell et al., 2000). Several researchers have monitored the water quality by fish analysis, because higher and relatively stable concentrations would be obtained for fish samples compared with the water itself (Adeyeye, 1994; Yamazaki et al., 1996; Camusso et al., 1998). Thus, fishes have been proposed as bioindicators to monitor a variety of contaminants in the marine ecosystem (Astorga-Espana et al., 1999).

The purpose of this study is therefore, to investigate some selected trace metals $(\mathrm{Zn}, \mathrm{Fe}, \mathrm{Cu}$,

\footnotetext{
* Author to whom all correspondence should be addressed.
} 
$\mathrm{Cd}, \mathrm{Pb}, \mathrm{Ni}, \mathrm{Co}$ and $\mathrm{Mn}$ ) concentrations in edible parts of Tilapia Oreochromis niloticus and Catfish Clarias gariepinus of Lake Awassa and Lake Ziway, and to evaluate the quality of these fishes on the basis of their trace metals contents. Oreochromis niloticus and Clarias gariepinus are selected in this study since these species are commercially exploited in both lakes and commonly found in other lakes and rivers in Ethiopia. Results obtained will establish baseline data on trace metals in aquatic resources and will enable evaluation of future trends in environmental contamination in Ethiopia.

\section{MATERIALS AND METHODS}

\section{Study area}

Lake Awassa: This lake is believed to be volcanotectonic in origin. Lake Awassa is located 6 $6^{\circ} 33^{\prime}-$ $7^{\circ} 33^{\prime} \mathrm{N}$ latitude and $38^{\circ} 22^{\prime}-39^{\circ} 29^{\prime} \mathrm{E}$ longitude (Demeke Admassu, 1989). It has an altitude of 1680 $\mathrm{m}$. Lake Awassa has an area of $88 \mathrm{~km}^{2}$, a maximum depth of $22 \mathrm{~m}$ and a mean depth of $11 \mathrm{~m}$ (Elias Dadebo, 2000). The Tikurwuha River at the northeastern shore is the only inlet (Demeke Admassu, 1989). The intensive cultivation of the surroundings of the lake and atmospheric deposition of particulate matter may cause pollution of the lake. Furthermore, Lake Awassa is likely to be affected by industrial sources because its in-flow (Tikurwuha) receives effluents from the Awassa Textile Factory and Tabor Ceramic Factory.

Lake Ziway: It lies within a broad down faulted basin. The lake contains five main islands (Tulu Gudo, Gelila, Tedecha, Funduro and Debre Sina) of volcanic origin (Schroder, 1984). Lake Ziway is located $7^{\circ} 52^{\prime}-8^{\circ} 8^{\prime} \mathrm{N}$ latitude and $38^{\circ} 40^{\prime}-38^{\circ} 56^{\prime} \mathrm{E}$ longitude (Makin et al., 1975). The altitude of Lake Ziway is $1636 \mathrm{~m}$ above sea level. It has an area of $440 \mathrm{~km}^{2}$, a maximum depth of $8.9 \mathrm{~m}$ and a mean depth of $2.5 \mathrm{~m}$ (Tenalem Ayenew, 1998). Lake Ziway is fed by the two major rivers Meki and Katar, which drain from the Northwestern and Southeastern plateaus, respectively (Von Damm and Edmond, 1984). Lake Ziway is being used for irrigation purposes and much of the land around it is under continuous cultivation, which may cause contamination of fish. Like Lake Awassa, Lake Ziway is also prone to contamination from land degradation and consequent atmospheric deposition.

\section{Sampling of fresh fish}

Samples were collected from three stations in each of Lakes Awassa and Ziway in February 1 and 2, 2002, respectively. Minch, Tikurwuha and Deset served as sampling sites in Lake Awassa, whereas Shalo, Kofe and Koli in Lake Ziway (Figures 1 and 2). Two fish species, Catfish and Tilapia were caught with gill net from each sampling location of the Lakes. The fishes were dissected with plastic knife and stomach contents were purged. The fish samples were wrapped with plastic bags and placed in an icebox and transported to the Laboratory. Samples were then stored at $-20^{\circ} \mathrm{C}$ until taken out for drying.

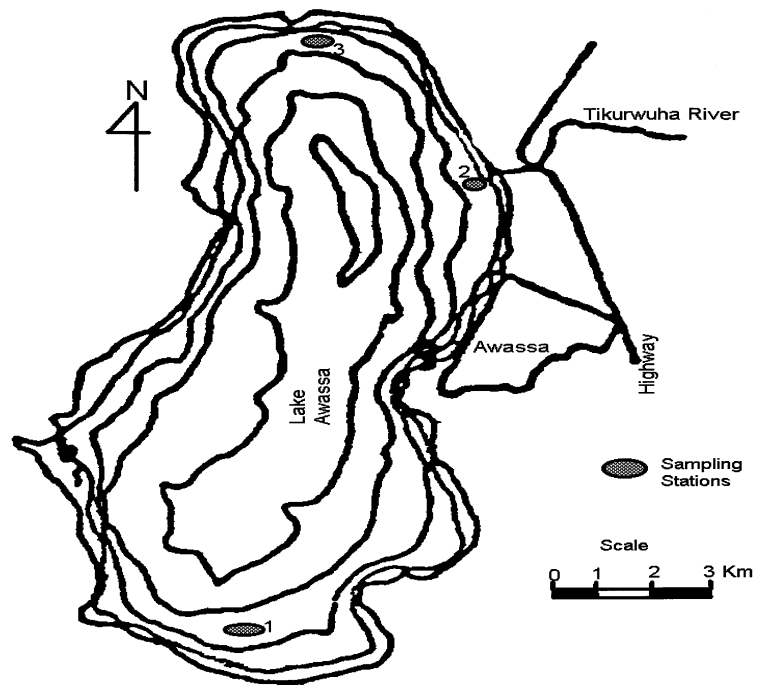

Fig. 1. Sampling stations in Lake Awassa: 1) Minch; 2) Tikurwuha; 3) Deset.

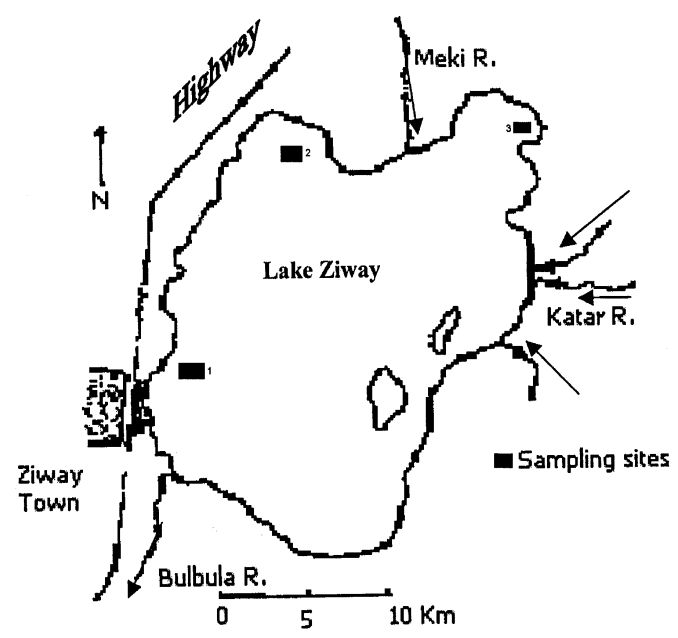

Fig. 2. Sampling sites in Lake Ziway: 1) Shalo; 2) Kofe; 3) Koli. 


\section{Sample preparation}

The edible muscle of fish was separated with plastic knife and placed in a $100 \mathrm{~mL}$ volumetric flask. Wet mass was determined and the edible tissue was placed in a freeze-drying unit (Freeze Dry-3, Labconco, Kansas City, Missouri) for seven days until constant mass was obtained. The lyophilized fish was ground and homogenized in a blending device (Moulinex, France). The procedure developed by Van Loon (1985) was tested for the digestion of $2.0 \mathrm{~g}$ of powdered fish with a mixture of concentrated solutions of $\mathrm{HNO}_{3}$ (SpectrosoL, $\mathrm{BDH}), 98 \% \mathrm{H}_{2} \mathrm{SO}_{4}$ (AnalaR, $\mathrm{BDH}$ ) and $35 \% \mathrm{H}_{2} \mathrm{O}_{2}$ (Riedel-de Haen, Germany) (Table 1). Different modifications of this procedure obtained by varying types of reagents and temperature of digestion were subsequently tested (Table 1).

Besides digesting the fish muscle completely, the procedure shown in step (VI) consumed less reagent volume and required short digestion time. This procedure was carried out as follows: A $2.0-\mathrm{g}$ aliquot of the dried and homogenized fish was added to a $100 \mathrm{~mL}$ round bottom flask. To the flask $4.0 \mathrm{~mL}$ of $70 \% \mathrm{HNO}_{3}$ was added followed by 2.0 $\mathrm{mL}$ of $98 \% \mathrm{H}_{2} \mathrm{SO}_{4}$.
When the reaction subsided, the flask fitted with water-cooled reflux condenser was placed in a Kjeldahl apparatus (Gallenkamp, Germany), heated to $100 \pm 5^{\circ} \mathrm{C}$ and the contents were boiled for 30 minutes under reflux. The flask was removed from the Kjeldahl apparatus and allowed to cool for 5 minutes. The flask was placed in the Kjeldahl apparatus after adding another $4.0 \mathrm{~mL}$ $\mathrm{HNO}_{3}$. The temperature was then increased to $190^{\circ}$ $\mathrm{C}$ and the contents were heated at $190 \pm 5^{\circ} \mathrm{C}$ for 2 hours, while the sample was boiling under reflux. The condenser was removed and the sample was heated near to dryness for 20 to 25 minutes at $190 \pm$ $5^{\circ} \mathrm{C}$. The flask was then removed and allowed to cool for 5 minutes. A $10.0 \mathrm{~mL}$ aliquot of hydrogen peroxide $(35 \%)$ was added in $2.0 \mathrm{~mL}$ portions and the contents were heated at $190 \pm 5^{\circ} \mathrm{C}$ while the sample was boiling under reflux until clear solution was obtained. The flask was removed from the Kjeldahl apparatus and the contents were cooled for 5 minutes. With a long glass dropper, the colorless solution in the digestion flask and the washings were carefully transferred to $25 \mathrm{~mL}$ volumetric flask and diluted to volume with distilled water.

Table 1. Procedures tested for the digestion of $\mathbf{2 . 0} \mathrm{g}$ of dried and powdered fish samples. Digestion reagents are added in the order listed with reagent volumes shown in brackets. The concentration of reagents are given in sample preparation section above.

\begin{tabular}{|c|c|c|c|c|c|c|}
\hline \multirow[b]{2}{*}{ Procedure } & \multirow[b]{2}{*}{ Condition } & \multirow[b]{2}{*}{ Reagents added $(\mathrm{mL})$} & \multicolumn{2}{|c|}{ Temperature $\left({ }^{\circ} \mathrm{C}\right)$} & \multirow{2}{*}{$\begin{array}{c}\begin{array}{c}\text { Nature of } \\
\text { digest }\end{array} \\
\end{array}$} & \multirow{2}{*}{$\begin{array}{l}\text { Digestion } \\
\text { time }(\mathrm{h}) \\
\end{array}$} \\
\hline & & & Initial & Final & & \\
\hline \multirow[t]{2}{*}{ Van Loon (1985) } & No refluxing & $\begin{array}{l}\text { a. } \mathrm{HNO}_{3}(4) \\
\text { b. } \mathrm{H}_{2} \mathrm{SO}_{4}(2) \\
\text { c. } \mathrm{HNO}_{3}(4) \\
\text { d. } \mathrm{H}_{2} \mathrm{O}_{2}(22)\end{array}$ & 60 & 150 & Clear & 11 \\
\hline & Refluxed & $\begin{array}{l}\text { a. } \mathrm{HNO}_{3}(2) \\
\text { b. } \mathrm{H}_{2} \mathrm{SO}_{4}(2) \\
\text { c. } \mathrm{HNO}_{3}(4) \\
\text { d. } \mathrm{H}_{2} \mathrm{O}_{2}(16)\end{array}$ & $60 \pm 5$ & $150 \pm 5$ & Clear & 10 \\
\hline II & Refluxed & $\begin{array}{l}\text { a. } \mathrm{HNO}_{3}(4) \\
\text { b. } \mathrm{H}_{2} \mathrm{SO}_{4}(2) \\
\text { c. } \mathrm{HClO}_{4}(2) \\
\text { d. } \mathrm{H}_{2} \mathrm{O}_{2}(14)\end{array}$ & $100 \pm 5$ & $190 \pm 5$ & Turbid & 10 \\
\hline III & Refluxed & $\begin{array}{l}\text { a. } \mathrm{HNO}_{3}(4) \\
\text { b. } \mathrm{H}_{2} \mathrm{O}_{2}(2) \\
\text { c. } \mathrm{HNO}_{3}(2) \\
\text { d. } \mathrm{H}_{2} \mathrm{O}_{2}(12)\end{array}$ & $100 \pm 5$ & $190 \pm 5$ & Clear & 9.5 \\
\hline IV & Refluxed & $\begin{array}{l}\text { a. } \mathrm{HNO}_{3}(4) \\
\text { b. } \mathrm{HClO}_{4}(2) \\
\text { c. } \mathrm{H}_{2} \mathrm{O}_{2}(16)\end{array}$ & $110 \pm 5$ & $200 \pm 5$ & Turbid & 9.0 \\
\hline $\mathbf{V}$ & Refluxed & $\begin{array}{l}\text { a. } \mathrm{HNO}_{3}(4) \\
\text { b. } \mathrm{HClO}_{4}(10)\end{array}$ & $110 \pm 5$ & $200 \pm 5$ & Turbid & 10 \\
\hline VI & Refluxed & $\begin{array}{l}\text { a. } \mathrm{HNO}_{3}(4) \\
\text { b. } \mathrm{H}_{2} \mathrm{SO}_{4}(2) \\
\text { c. } \mathrm{HNO}_{3}(4) \\
\text { d. } \mathrm{H}_{2} \mathrm{O}_{2}(10)\end{array}$ & $100 \pm 5$ & $190 \pm 5$ & Clear & 7.0 \\
\hline
\end{tabular}




\section{Determination of trace metals}

Standard stock solutions (BUCK SCIENTIFIC) that contained $1000 \mathrm{ppm}$ of metals were systematically diluted to obtain a series of working standards (0.1-3.6 $\mu \mathrm{g}$ metal/g). Three standard solutions were prepared for each metal. A blank solution and the standards were run in the atomic absorption spectrophotometer (BUCK SCIENTIFIC MODEL 210VGP) with air-acetylene flame and four point calibration curves were established. Sample solutions were each aspirated into the atomic absorption spectrophotometer (AAS) and direct readings of metal concentrations were recorded. Three replicate determinations were carried out on each sample.

\section{Recovery study}

Two alternative techniques were used to evaluate the recovery of the digestion procedure. In the first case, a mixture of the standard solutions was digested in triplicate employing the optimized digestion procedure. Accordingly, aliquots $(50 \mu \mathrm{L})$ of $\mathrm{Fe}, \mathrm{Zn}$, $\mathrm{Co}$ and $\mathrm{Ni}$; $25 \mu \mathrm{L}$ of $\mathrm{Pb}$; and $10 \mu \mathrm{L}$ of $\mathrm{Cu}$, $\mathrm{Cd}$ and $\mathrm{Mn}$ were taken from the corresponding 1000-ppm stock standard solutions and transferred into a $100 \mathrm{~mL}$ round bottom digestion flasks. Digestion was done as described above for fish sample. The digests and the corresponding washings of the flask were carefully transferred into a $25 \mathrm{~mL}$ volumetric flask using a clean long glass dropper. The contents were diluted to volume and concentrations of the metals in the standards were determined with AAS using external calibration graphs as described above.

In the second case, a $2.0 \mathrm{~g}$ sample of the powdered fish was spiked with measured volumes of standard solutions of the metals: aliquots of $\mathrm{Zn}$, $\mathrm{Fe}, \mathrm{Pb}, \mathrm{Ni}$ and $\mathrm{Co}$ (each $25 \mu \mathrm{L}, 1000 \mathrm{ppm}$ ) and $\mathrm{Cu}$, $\mathrm{Cd}, \mathrm{Mn}$ (each $10 \mu \mathrm{L}, 1000 \mathrm{ppm}$ ) were added to the digestion flask containing the powdered fish tissue. The digestion reagents were added in the order shown in Table 1 and the optimized digestion procedure was applied. The resulting clear digests and washings were transferred into volumetric flask and diluted to $25 \mathrm{~mL}$. Trace metals were determined with AAS using external calibration curve.

\section{RESULTS}

\section{Dry mass determination}

In order to attain comparability between different fish species and samples, determination of dry mass of fish samples was necessary. Edible portions of each fish sample (O. niloticus or $C$. gariepinus) obtained from six sampling sites in Lakes Awassa and Ziway were placed separately in $100 \mathrm{~mL}$ thick-walled flasks and freeze-dried for seven days to constant mass. The percent loss in mass of fish was calculated as moisture content. The calculated percentage moisture content of the two fish species obtained from different spots in the two lakes varied from $79.3 \%-82.5 \%$ (Figure 3).

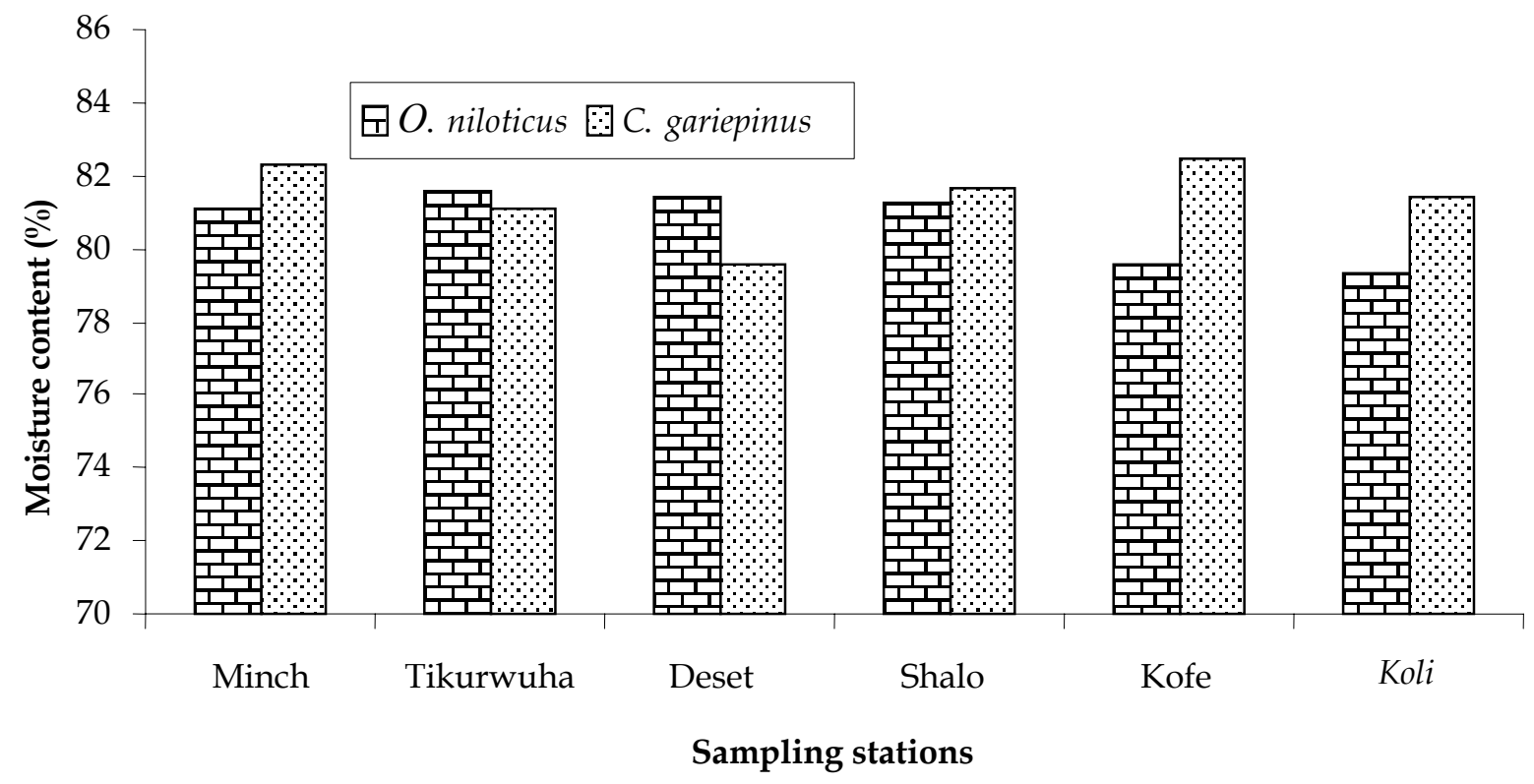

Fig. 3. Moisture contents of fishes collected from Lakes Awassa and Ziway. 


\section{Efficiency of the optimised digestion procedure}

Efficiency of the optimised digestion method was checked by mineralizing standard solutions of metals or spiked fish samples. The digests of standard solutions were diluted and trace elements were determined using AAS. Recoveries of metals in standard solutions analyzed gave values between $98.50 \%$ and $123.25 \%$. Fish samples spiked with standard solutions of trace metals and digested following the optimal protocol yielded recoveries ranging from $92.5 \%-120 \%$ (Figure 4 ).

\section{Concentrations of trace metals}

The results on metals in fishes from Lake Awassa and Lake Ziway are compiled in Table 2. Zinc concentrations in fishes from the two lakes varied from $23.04-30.92 \mu \mathrm{g} / \mathrm{g}$ dry masses. Iron ranged from 19.25-59.75 $\mu \mathrm{g} / \mathrm{g}$, with highest concentration found in Clarias gariepinus from Koli station in Lake Ziway. Copper concentrations varied from 1.03-2.78 $\mu \mathrm{g} / \mathrm{g}$ for the two species from both lakes. Manganese concentrations ranged from 1.54-4.46 $\mu \mathrm{g} / \mathrm{g}$, with the highest concentration found in Oreochromis niloticus from Tikurwuha station in Lake Awassa. The results obtained for cadmium, lead, nickel and cobalt for all samples were below the limits of detection, 0.24 , $1.66,0.99$ and $0.71-\mu \mathrm{g} / \mathrm{g}$ dry mass, respectively.

\section{DISCUSSION}

\section{Selection of sampling sites}

Selection of sampling stations shown in Figures 1 and 2 was based on site observation and personal discussions with fishermen and local community about the features of the lakes. On the basis of such considerations, sites nearer to and away from point sources were selected. Moreover, availability of species of interest was considered in site selection. Accordingly, Tikurwuha was chosen as a site prone to industrial and agricultural contamination, whereas Minch as a station away from point sources in Lake Awassa. Moreover, Deset was chosen as sampling site in Lake Awassa due to availability of fish species of special physique. Similarly, Koli and Kofe stations in Lake Ziway were chosen as sites liable to agricultural and domestic wastes, whereas Shalo station as a site away from such anthropogenic influences. Thus, the sites chosen in our investigation were anticipated to represent the status of the lakes with respect to variations in trace element concentrations. Thus, analyzing fishes from these sites may indicate any associated pollution.

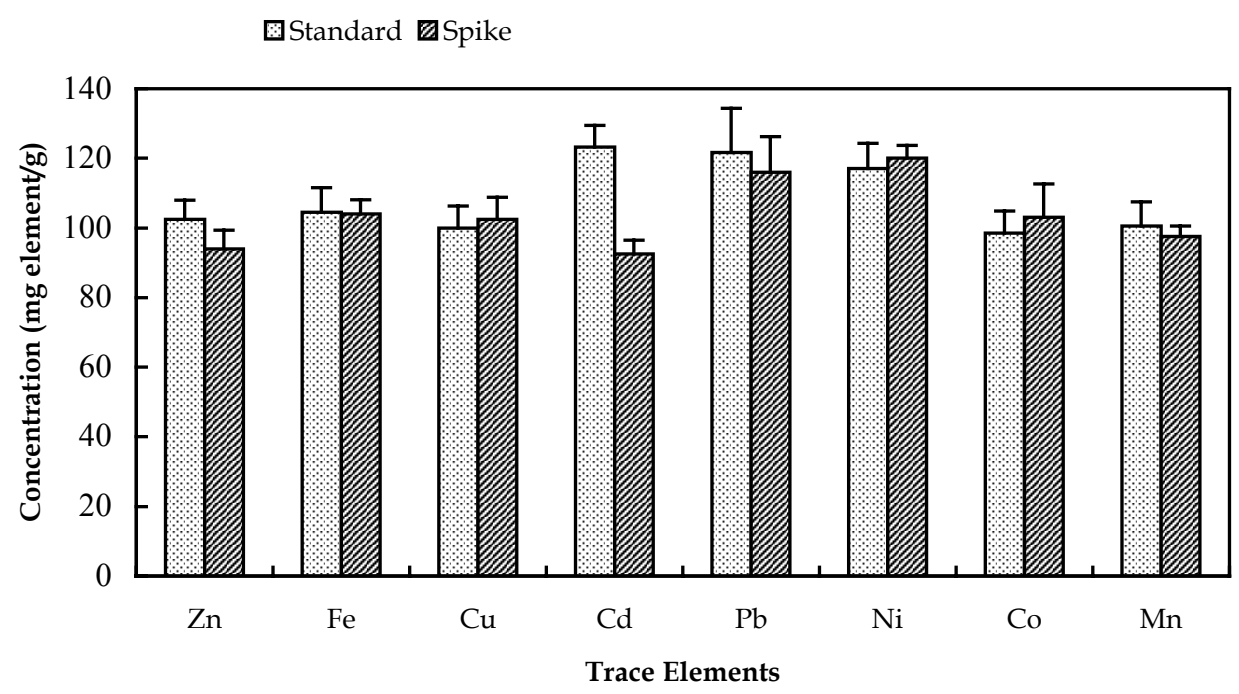

Fig. 4. Recovery of trace metals in a mixture of standard solutions and spiked fish samples. 
Table 2. Trace metal concentrations (mean \pm SD; $\mu$ g metal/g dry mass) of selected fish species in Lakes Awassa and Ziway $(\mathrm{n}=3)$.

\begin{tabular}{|c|c|c|c|c|c|c|c|c|c|}
\hline \multirow{2}{*}{$\begin{array}{l}\text { Sampling } \\
\text { site }\end{array}$} & \multirow[t]{2}{*}{ Fish species } & \multicolumn{8}{|c|}{ Concentration of metals $(\mu \mathrm{g} / \mathrm{g})$} \\
\hline & & $\mathrm{Zn}$ & $\mathrm{Fe}$ & $\mathrm{Cu}$ & $C d$ & $\mathrm{~Pb}$ & $\mathrm{Ni}$ & Co & $\mathrm{Mn}$ \\
\hline \multirow[t]{2}{*}{ Minch } & O. niloticus & $27.00 \pm 2.16$ & $32.38 \pm 2.13$ & $1.85 \pm 0.21$ & $<0.24$ & $<1.66$ & $<0.99$ & $<0.71$ & $2.56 \pm 0.31$ \\
\hline & C. gariepinus & $26.04 \pm 1.92$ & $27.19 \pm 0.19$ & $1.63 \pm 0.53$ & $<0.24$ & $<1.66$ & $<0.99$ & $<0.71$ & $1.79 \pm 0.11$ \\
\hline \multirow[t]{2}{*}{ Tikurwuha } & O. niloticus & $24.04 \pm 1.88$ & $31.81 \pm 2.69$ & $1.71 \pm 0.06$ & $<0.24$ & $<1.66$ & $<0.99$ & $<0.71$ & $4.46 \pm 0.39$ \\
\hline & C. gariepinus & $23.75 \pm 0.89$ & $31.69 \pm 4.19$ & $1.52 \pm 0.33$ & $<0.24$ & $<1.66$ & $<0.99$ & $<0.71$ & $1.76 \pm 0.11$ \\
\hline \multirow[t]{2}{*}{ Deset } & O. niloticus & $24.42 \pm 1.91$ & $22.94 \pm 2.69$ & $1.39 \pm 0.16$ & $<0.24$ & $<1.66$ & $<0.99$ & $<0.71$ & $1.74 \pm 0.08$ \\
\hline & C. gariepinus & $23.04 \pm 1.93$ & $27.13 \pm 0.13$ & $1.44 \pm 0.09$ & $<0.24$ & $<1.66$ & $<0.99$ & $<0.71$ & $1.54 \pm 0.09$ \\
\hline \multirow[t]{2}{*}{ Shalo } & O. niloticus & $30.92 \pm 0.65$ & $19.25 \pm 1.25$ & $1.98 \pm 0.04$ & $<0.24$ & $<1.66$ & $<0.99$ & $<0.71$ & $1.66 \pm 0.05$ \\
\hline & C. gariepinus & $25.21 \pm 1.75$ & $38.88 \pm 0.75$ & $2.78 \pm 0.34$ & $<0.24$ & $<1.66$ & $<0.99$ & $<0.71$ & $1.99 \pm 0.16$ \\
\hline \multirow[t]{2}{*}{ Kofe } & O. niloticus & $28.04 \pm 0.95$ & $20.44 \pm 1.44$ & $1.34 \pm 0.22$ & $<0.24$ & $<1.66$ & $<0.99$ & $<0.71$ & $1.93 \pm 0.13$ \\
\hline & C. gariepinus & $26.54 \pm 1.45$ & $30.00 \pm 0.50$ & $1.55 \pm 0.28$ & $<0.24$ & $<1.66$ & $<0.99$ & $<0.71$ & $1.76 \pm 0.04$ \\
\hline \multirow[t]{2}{*}{ Koli } & O. niloticus & $26.29 \pm 0.77$ & $29.50 \pm 7.63$ & $1.03 \pm 0.14$ & $<0.24$ & $<1.66$ & $<0.99$ & $<0.71$ & $2.13 \pm 0.19$ \\
\hline & C. gariepinus & $29.88 \pm 1.74$ & $59.75 \pm 10.38$ & $2.75 \pm 0.53$ & $<0.24$ & $<1.66$ & $<0.99$ & $<0.71$ & $2.49 \pm 0.39$ \\
\hline
\end{tabular}

\section{Water content of fishes}

Use of dry masses rather than wet provides a more accurate measure of metal load since water content in biota varies with species, age, condition, etc. Moreover, comparisons between fishes can easily be made on dry mass basis. For this reason, water content was removed from the edible muscle of fishes by freeze-drying until constant mass was obtained. Such a determination resulted in the average water content of $81.06 \pm 1.00 \%$ in the edible muscle. This transpires to a wet mass/dry mass ratio of 5.3 taking wet mass as $100 \%$ and dry mass as $\sim 19 \%$. Zauke et al. (1999) reported moisture content of $82 \%$ with wet mass/dry mass ratio of 5.6 for muscle, which is in good agreement with our data validating our method of moisture content determination. However, the moisture content of fish muscle reported by Windom et al. (1973) ranged from 65 to $78 \%$ for all samples analysed. The observed difference between our data and that of Windom et al. (1973) could probably be attributed to difference in methods of determination. In our study, the water contents reveal absence of interspecies difference between fishes from the two lakes.

\section{Digestion of fish samples}

To transfer trace elements in fish tissues into aqueous solutions, appropriate digestion procedures are required. Such procedures permit the use of inorganic salts as calibration standards for the determination of trace elements in fishes. It is important that such procedures avoid analyte loss and be free from risk of contamination. Literature reports (Bock, 1979; Evans et al., 1986) recommend different combinations of mineral acids with hydrogen peroxide to mineralise fish tissue in open vessels. However, many of such procedures used to digest fish tissue require long digestion times or large reagent volumes.

In this study, different digestion procedures were tested to mineralize dried and powdered fish samples. We wished to reduce the time taken, the volume of reagent consumed as well as to minimize contamination. At the beginning, the open-vessel digestion procedure developed by Van Loon (1985) was repeated to digest $2.0 \mathrm{~g}$ of dried fish sample. Such attempt gave clear solutions but the procedure consumed larger reagent volumes and required longer digestion time. As it consumed larger volume of reagents and required longer digestion time modification of Van Loon's procedure was necessary. Procedures I, III and VI (Table 1) consumed less reagent volumes and required shorter digestion times than Van Loon's procedure (Van Loon, 1985). Possible explanation for this difference could presumably be attributed to the use of open systems without refluxing by Van Loon, which could lead to loss of solvents, by volatilisation. Moreover, Van Loon's procedure could very likely be prone to contamination and losses of analytes due to volatilisation. Refluxing 
has the advantage in decreasing blank values due to reduced reagent volumes and decreased contamination from the laboratory environment. Furthermore, increasing initial temperature of digestion coupled with refluxing considerably reduced the time required for digestion and the volume of reagents needed.

\section{Validation of the optimized digestion procedure}

The accuracy of the optimal digestion procedure was evaluated by analyzing digests of standard stock solutions and spiked fish samples. The purpose of spiking experiment was to gain idea whether the investigated heavy metals are lost or gained during the digestion procedure under the given experimental conditions. In principle, the digestion procedure converts the heavy metals into inorganic form. Some of the inorganic heavy metals have the tendency to be lost or gained during the prolonged digestion procedure that has been employed. Any effect on the heavy metals in the fish tissue should apparently occur on the spiked metals. Such loss or gain of heavy metals should manifest itself in an increase or a decrease of the added metal concentrations, which enables evaluation of matrix effects as well. Good recoveries were obtained for zinc, iron, copper, cobalt and manganese, confirming the validity of the method developed. However, somewhat elevated recoveries were observed for cadmium, lead and nickel. Contaminants from reagents and vessels employed in the analysis may be responsible for these elevated recoveries. This was also evidenced by high blank concentrations for cadmium, lead and nickel. Similarly, trace metals were also recovered quantitatively from spiked fish samples. Recoveries from digests of standard solutions and spiked fish samples were in close agreement for $\mathrm{Zn}, \mathrm{Fe}, \mathrm{Cu}, \mathrm{Pb}, \mathrm{Ni}$, $\mathrm{Co}$ and $\mathrm{Mn}$ (Figure 4), whereas, lower recovery of $\mathrm{Cd}$ was recorded in spiked fish samples. This may be attributed to the matrix effect of spiked fish digests.

\section{Trace metals in fishes}

The concentrations of eight trace metals $(\mathrm{Zn}, \mathrm{Fe}$, $\mathrm{Cu}, \mathrm{Cd}, \mathrm{Pb}, \mathrm{Ni}, \mathrm{Co}$ and $\mathrm{Mn}$ ) in the digested and diluted solutions of fish tissues were determined with flame AAS employing external calibration method (Table 2). The elements $\mathrm{Cd}, \mathrm{Pb}, \mathrm{Ni}$ and $\mathrm{Co}$ were found below the detection limits in both fish species obtained from both lakes.

The t-test statistical method was employed to permit evaluation of possible interrelationships among the concentrations of metals in fishes. Applying t-test at 95 percent confidence level, the results revealed absence of significant difference in concentrations of the analyzed trace metals between Oreochromis niloticus and Clarias gariepinus in Lake Awassa. Similarly, no interspecies variability was observed in concentrations of all trace metals in Lake Ziway. Moreover, the differences in concentrations of trace metals among Oreochromis niloticus of both lakes were not significant. The variation of concentrations of trace metals among Clarias gariepinus of Lake Awassa and Lake Ziway was also insignificant. Absence of significant difference in the concentrations of trace elements in fishes might indicate absence of a distinctly pronounced influence from the environment in one of the lakes.

Lakes Awassa and Ziway belong to the same geochemical setting. Moreover, both lakes are prone to influences of anthropogenic origin, mainly related to agricultural activities and to atmospheric deposition of particulate matter. In addition, Lake Awassa receives industrial waste from the Awassa Textile Factory and the Tabor Ceramic Factory. Unpublished reports on the effluents of these two factories showed occurrence of several heavy metals at relatively higher concentrations than the lake water. Consequently, worries concerning possible contamination of the lake with effluents from the Tabor Ceramic and Awassa Textile Factories have been discernible.

The results of this study have shown the accumulation of zinc, iron, copper and manganese in edible parts of Oreochromis niloticus and Clarias gariepinus. However, the results do not suggest the presence of any noticeable artificial contamination of fishes. This is evidenced by the low levels of cadmium and lead (below detection limit, Table 2) in fish muscles. Although a human impact within the catchments is not absent, those detected elements seem to be mainly geologically derived. Since thermal springs can be sources of heavy metals, the continuous input from such sources into fresh surface water bodies can change the overall chemical composition of the water. Furthermore, the lakes serve as major destination points for deep mineralized thermal water (Tamiru Alemayehu, 2000). With increasing rate of deforestation in the catchment areas, surface run off could contribute to the total stock of trace elements in the lakes. 
While trace metal levels in analyzed fish species from Lakes Awassa and Ziway were not appreciable, despite anthropogenic pressure in the area (Zinabu Gebre Mariam and Elias Dadebo, 1989) the impacts on fishes of Lakes Awassa and Ziway will certainly be detectable in the near future. Since both lakes are in the neighborhood of fast growing cities, it is very likely that more domestic and industrial waste will find way directly into the lakes and elevate the levels of trace metals in fishes. The studies on trace metal accumulation in Clarias gariepinus exposed to sublethal levels of tannery effluent by Gbem $e t$ al. (2001) in Nigeria indicated the accumulation of metals to be concentration and time dependent. As a matter of fact, the fishes of Lakes Awassa and Ziway could presumably accumulate high metal concentrations with industrialization through time. Therefore, before irreversible changes occur, it is wise to show concern right from the start of industrialisation.

Although there are interspecies differences in the uptake by and fate of elements in fish, no published data on species under study are available. Therefore, we found it plausible to compare muscle concentrations of metals determined in the present study with reported values of other species. Even though higher concentrations of zinc and iron than other metals in both species were obtained, these values are not exceptionally high when compared to reported values from different fish species (Table 3). The concentration of iron reported by John et al. (1977) from Brook silverside species collected from Par Pond of South Carolina was $149.3 \mu \mathrm{g} / \mathrm{g}$ dry mass. Cohen et al. (2001) found $650 \mu \mathrm{g} / \mathrm{g}$ zinc and 440 $\mu \mathrm{g} / \mathrm{g}$ copper in Tagelus californianus from Ballona Lagoon of California Coastal Wetland.
These values are very much higher than the highest values obtained in our study for zinc (30.92 $\mu \mathrm{g} / \mathrm{g})$ and copper $(2.78 \mu \mathrm{g} / \mathrm{g})$.

Cohen et al. (2001) also reported $0.90 \mu \mathrm{g} / \mathrm{g}$ of cadmium, $6.8 \mu \mathrm{g} / \mathrm{g}$ of lead and $37 \mu \mathrm{g} / \mathrm{g}$ of nickel. Windom et al. (1973) detected cadmium as high as $1.6 \mu \mathrm{g} / \mathrm{g}$ from some species of North Atlantic Finfish. However, the concentrations of cadmium, lead and nickel are below detection limits in all samples we investigated. The accumulation of metals like $\mathrm{Cu}$ in fish is higher than that of $\mathrm{Pb}$, because of the important biochemical functions in the organism, which includes participation as in complex enzymes.

Glover (1979) recorded concentrations of zinc (4.8 $\mu \mathrm{g} / \mathrm{g})$, copper $(0.6 \mu \mathrm{g} / \mathrm{g})$, cadmium $(0.08$ $\mu \mathrm{g} / \mathrm{g})$, lead $(<0.1 \mu \mathrm{g} / \mathrm{g})$, nickel $(<0.2 \mu \mathrm{g} / \mathrm{g})$, cobalt $(<0.3 \mu \mathrm{g} / \mathrm{g})$ and manganese $(0.6 \mu \mathrm{g} / \mathrm{g})$ on wet mass basis from fishes in South-eastern Australian Waters. A definitive comparison among concentrations of trace elements in fishes from Lakes Awassa and Ziway may be made with literature values only when the geological setting, environmental and climatic conditions are known unambiguously. Without concern to this fact, the values obtained in the present study are found to lie within the same range to Glover's data (1979) as shown in Table 6 on wet mass basis. However, cadmium has been found to be an exception. Astorga-Espana et al. (1999) determined $29.6 \mu \mathrm{g} / \mathrm{g}$ of $\mathrm{Zn}$ and $23.9 \mu \mathrm{g} / \mathrm{g}$ of Fe in fish from Canary Islands. These values are also within the same range of concentrations of the corresponding metals in fishes from Lakes Awassa and Ziway (Table 3).

Table 3. Comparison of trace metal concentrations in fishes from Lakes Awassa and Ziway with literature reports $(\mu \mathrm{g} / \mathrm{g}$ wet mass or dry mass).

\begin{tabular}{|c|c|c|c|c|c|c|c|c|c|c|}
\hline Location & $\mathrm{Zn}$ & $\mathrm{Fe}$ & $\mathrm{Cu}$ & $\mathrm{Cd}$ & $\mathrm{Pb}$ & $\mathrm{Ni}$ & $\mathrm{Co}$ & Mn & Basis $^{a}$ & Ref. \\
\hline L. Awassa & 27.00 & 32.38 & 1.85 & $<0.24$ & $<1.66$ & $<0.99$ & $<0.71$ & 4.46 & d.m. & Present study \\
\hline L. Ziway & 30.92 & 59.75 & 2.78 & $<0.24$ & $<1.66$ & $<0.99$ & $<0.71$ & 2.49 & d.m. & Present study \\
\hline N. Atlantic Ocean & 397 & & 23.0 & 1.6 & & & & & d.m. & Windom et al. (1973) \\
\hline S. Carolina & 232.9 & 149.3 & 5.56 & 0.87 & & & & & d.m. & John et al. (1977) \\
\hline Barents Sea & 62.0 & & 3.4 & $<0.1$ & $<0.3$ & $<1.0$ & & & d.m. & Zauke et al. (1999) \\
\hline C. Coastal Wetlands & 650 & & 440 & 0.9 & 6.8 & 37 & & & d.m. & Cohen et al.(2001) \\
\hline SE Australian Waters & 4.8 & & 0.6 & 0.08 & $<0.1$ & $<0.2$ & $<0.3$ & 0.6 & w.m. & Glover (1979) \\
\hline Canary Islands & 29.6 & 23.9 & 0.05 & & & & & & d.m. & $\begin{array}{l}\text { Astorga-Espana et al. } \\
\text { (1999) }\end{array}$ \\
\hline
\end{tabular}

ad.m.- dry mass; w.m.- wet mass 
Comparison between trace metals concentrations in fishes and in lake waters

Table 4 shows the concentrations of trace metals in fishes of Lake Awassa and reported concentrations of metals in the lake water (Telford, 1998). In surface waters, all trace metals (contaminants associated with the influent waste as well as of other origin) exist in colloidal particulate and dissolved phases (Buffle and De Vitre, 1994), although dissolved concentrations are generally low. The colloidal and particulate metal may be found in 1) hydroxides, oxides, silicates, or sulfides; or 2) adsorbed to clay, silica, or organic matter. Evidently, trace metals that enter surface waters may partition into other compartments of the lake such as sediments, plants, minerals and organic matter. Uptake by biota depends on the ability of metals to cross the biological membrane, a phenomenon referred to bioavailability. It is only the bioavailable form of the metal that may accumulate in the tissue of the organism and may become essential, non-essential, or toxic to the biota.

Table 4. Comparison of concentrations of trace metals in fishes of Lake Awassa with reported concentration of lake water (Telford, 1998).

\begin{tabular}{lcc}
\hline Element & $\begin{array}{c}\text { Concentration in } \\
\text { fishes }(\mu \mathrm{g} / \mathrm{g})\end{array}$ & $\begin{array}{c}\text { Concentration in } \\
\text { lake water }(\mu \mathrm{g} / \mathrm{L})\end{array}$ \\
\hline $\mathrm{Zn}$ & 27.00 & 90.11 \\
$\mathrm{Fe}$ & 32.38 & 210 \\
$\mathrm{Cu}$ & 1.85 & 5.39 \\
$\mathrm{Cd}$ & $<0.24$ & 0.47 \\
$\mathrm{~Pb}$ & $<1.66$ & 7.47 \\
$\mathrm{Ni}$ & $<0.99$ & 1.5 \\
$\mathrm{Co}$ & $<0.71$ & 0.07 \\
$\mathrm{Mn}$ & 4.46 & 24.54 \\
\hline
\end{tabular}

The portion that has become available to fishes and accumulated in their tissues has been of present interest partly because consumers are exposed to this fraction of trace elements. However, the results of this study showed absence of significant accumulation of trace metals in the edible tissues of fishes from lake Awassa. Perhaps, the heavy metals that entered the lake have been partitioned among the water column, sediment, and lake biota. The fraction accumulated in the tissues of fishes should be in bio-available form and was very low in concentration. As the concentration of metals in lake water increases the concentrations of the corresponding metals in fishes increase accordingly. This trend is demonstrated by our data and gives additional support to the validity of our data.

The concentration of cobalt in fishes apparently looks higher than that in water. However, $0.71 \mu \mathrm{g}$ $\mathrm{Co} / \mathrm{g}$ of fish listed in the table above was the minimum concentration detectable by our method and does not suggest a higher concentration than that in water.

A closer look at Table 4 shows a strong correlation between concentrations of trace elements in fishes and in the lake water, although the concentrations of trace metals in fishes are much higher than in the lake water. The concentrations of $\mathrm{Cu}, \mathrm{Mn}, \mathrm{Zn}$ and $\mathrm{Fe}$ in fishes increase with increasing concentration of these elements in the lake water. Thus, the investigated fishes seem to accumulate trace elements in their tissues and Oreochromis niloticus and Clarias gariepinus may be considered as important fish species for monitoring the level of trace metals.

\section{Comparison of trace metals in fishes with the European dietary standards and guidelines}

To evaluate whether metal levels found in fish samples from Lakes Awassa and Ziway are safe for human consumption, a comparison is made with reference values for fish muscles (Table 5). The validity of such comparison may appear questionable. However, in the absence of national standards and guidelines, a comparison of this kind may provide preliminary idea about safety levels of our lake water fishes. Dietary standards and guidelines have been summarized by Ministry of Agriculture, Food and Fisheries (MAFF, 1995). The guideline limits for cadmium, lead, copper and zinc are $0.2,2.0,20$ and $50 \mathrm{mg} / \mathrm{kg}$ wet mass, respectively. The range of reference values proposed and issued in some European countries is rather narrow. In Russia (Zauke et al., 1999), the maximum permissible value is $0.2 \mathrm{mg} \mathrm{Cd} / \mathrm{kg}, 1.0$ $\mathrm{mg} \mathrm{Pb} / \mathrm{kg}, 10 \mathrm{mg} \mathrm{Cu} / \mathrm{kg}$ and $40 \mathrm{mg} \mathrm{Zn/kg}$ (wet mass) whereas in Germany (Zauke et al., 1999), 0.10 
mg Cd kg-1 and $0.50 \mathrm{mg} \mathrm{Pb} \mathrm{kg}^{-1}$ (wet mass) considered as critical values.

The maximum concentration of zinc found in fishes from Lakes Awassa and Ziway was 5.83 $\mathrm{mg} / \mathrm{kg}$ wet mass. This value is about 7 times lower than the maximum permissible level (Zauke et al., 1999). The maximum concentration of copper (0.52 $\mathrm{mg} / \mathrm{kg}$ wet mass) detected in fishes from Lakes Awassa and Ziway was about 19 times lower than the critical value. The results for all fish samples analyzed in this study revealed low concentrations of $\mathrm{Cd}$ and $\mathrm{Pb}(<0.045 \mathrm{mg} \mathrm{Cd} / \mathrm{kg}$ and $<0.31 \mathrm{mg}$ $\mathrm{Pb} / \mathrm{kg}$ wet mass), which are below the detection limits. Since the maximum levels of these trace metals found in edible portion of fishes are far below the thresholds, the analyzed fish species may be considered as safe for human consumption relative to the analyzed elements.

Table 5. Comparison of concentrations of trace elements in fishes with European dietary standards and guidelines ( $\mathrm{mg} / \mathrm{kg}$ wet mass).

\begin{tabular}{llllll}
\hline $\begin{array}{l}\text { Parameter } \\
\text { (guidelines) }\end{array}$ & Zinc Copper & Cadmium & Lead & Ref. \\
\hline MAFF & 50 & 20 & 0.2 & 2.0 & $\begin{array}{l}\text { MAFF (1995) } \\
\text { Russia }\end{array}$ \\
40 & 10 & 0.2 & 1.0 & $\begin{array}{l}\text { Zauke } \text { et al. } \\
(1999)\end{array}$ \\
Germany & - & - & 0.1 & 0.5 & $\begin{array}{l}\text { Zauke } \text { et al. } \\
(1999)\end{array}$ \\
$\begin{array}{l}\text { Trace } \\
\text { elements } \\
\text { in fishes }\end{array}$ & 5.83 & 0.52 & $<0.045$ & $<0.31$ & $\begin{array}{l}\text { Present } \\
\text { study }\end{array}$ \\
\hline
\end{tabular}

\section{CONCLUSION AND RECOMMENDATIONS}

An efficient procedure for the digestion of edible tissue of fish has been developed and validated through recovery studies. Using the optimal digestion procedure, similar concentrations of trace metals in fishes (Oreochromis niloticus and Clarias gariepinus) from the two lakes were observed. Moreover, results revealed absence of any reliable interspecies differences in the content of trace metals in fish muscle tissue. Furthermore, Oreochromis niloticus and Clarias gariepinus tend to accumulate trace metals and thus, they may be considered as useful species for monitoring pollution of lakes by trace metals.

Although this data set is relatively small to draw authoritative conclusions about the status of the lakes, the survey has indicated the accumulation of trace metals ( $\mathrm{Zn}, \mathrm{Fe}, \mathrm{Cu}$ and $\mathrm{Mn}$ ) in fish muscle tissue and provided baseline data for comparison with possible future changes. However, compared to more industrialized regions, the concentrations of trace metals from fishes of Lakes Awassa and Ziway are low. The fish muscles in this study were also in safety baseline levels for human consumption relative to the analysed elements.

Even though our findings do not indicate the contamination of fishes by trace metals from Lakes Awassa and Ziway, it is wise to take control measures right from the initial stage of industrialization. Control measures and management practices such as afforestation of the catchment area and proper treatment of industrial as well as domestic waste before discharging into the lakes are necessary to minimize pollution of the lakes. Otherwise, it is not too far that the impacts from industrial wastes together with other human activities in Lake Awassa will become detectable in fishes. Since much of the land around Lake Ziway is under continuous cultivation, which may cause contamination of fishes, proper care and management are necessary before these resources are endangered.

To assess metal accumulation, we examined only the fish muscle, which is the most important part to be used for human consumption. However, other tissues and organs such as liver, kidney, gills, gut, bones and scales may be equally important for evaluating accumulation of certain elements in fishes. Thus, our future studies will focus on the analysis of trace metals in different organs of fishes, sediments and water to establish correlation between different environmental compartments.

\section{ACKNOWLEDGEMENTS}

Abayneh Ataro thanks the Department of Chemistry, Addis Ababa University, for laboratory facilities and the School of Graduate Studies, Addis Ababa University, for financial support.

\section{REFERENCES}

1. Adeyeye, E.I. (1994). Determination of trace heavy metals in Illisha africana fish and in associated water and soil sediments from some fishponds. Int. J. Environ. Stud. 45:231-238. 
2. Astorga-Espana, M.S., Pena-Mendez, E.M. and Garcia-Montelongo, F.J. (1999). Application of principal component analysis to the study of major cations and trace metals in fish from Tenerife (Canary Islands). Chemometrics and Intelligent Laboratory Systems 49:173-178.

3. Baumann, A., Forstner, U. and Rohde, R. (1975). Lake Shala water chemistry, mineralogy and geochemistry of sediments in an Ethiopian Rift Lake. Geol. Resch. 64:593-609.

4. Bock, R.A. (1979). Handbook of Decomposition Methods in Analytical Chemistry. The Blackie Group, London, pp. 195-246.

5. Buffle, J. and De Vitre, R.R. (1994). Chemical and Biological Regulation of Aquatic Systems. Lewis Publishers, Boca Raton, pp. 9 and 89.

6. Camusso, M., Balestrini, R. and Crenscenzio, S. (1998). Trace metal accumulation in selected organs of fish from the Lower River Po. Verh.-Int. Ver. Theor. Angew. Limonl. 26(5):2194-2198.

7. Cohen, T., Shane, S.Q.H. and Richard, F.A. (2001). Trace metals in fish and invertebrates of three California Coastal Wetlands. Mar. Poll. Bull. 42: 229-232.

8. Demeke Admassu (1989). A Study on the Age Growth of Adult Oreochromis niloticus Linn. (Pisces: Clchlidae) in Lake Awassa, Ethiopia. M.Sc. Thesis, School of Graduate Studies, Addis Ababa University, pp. 8-11.

9. Elias Dadebo (2000). Reproductive biology and feeding habits of the Catfish Clarias gariepinus (Burchell) (Pisces: Clariidae) in Lake Awassa, Ethiopia. SINET: Ethiop. J. Sci. 23(2):231-246.

10. Evans, S.J., Johnson, M.S. and Leah, R.T. (1986). Determination of mercury in fish tissue. Varian, AA-60:1-6.

11. Farrell, A.P., Hodaly, A.H. and Wang, S. (2000). Metal analysis of scale taken from Arctic grayling. Arch. Environ. Contam. Toxicol. 39:515-522.

12. Gbem, T.T., Balogun, J.K., Lawal, F.A. and Annune, P.A. (2001). Trace metal accumulation in Clarias gariepinus (Teugels) exposed to sublethal levels of tannery effluent. Sci. Total Environ. 271:1-9.

13. Glover, J.W. (1979). Concentrations of arsenic, selenium and ten heavy metals in School Shark, Galeorhinus australis (Macleas), and Gummy Shark, Mustelus antarcticus Gunther, from South-eastern Australian Waters. Aust. J. Mar. Freshwater Res. 30:505-510.

14. Jerzy, S. (1995). Effect of heavy metals in the pond on production and breeding of fish. Ekol. Tech. 3(4):28-30.
15. John, P., Giesy, J.R. and James, G.W. (1977). Frequency distributions of trace metal concentrations in five freshwater fishes. Trans. Am. Fish. Soc. 106(4):393-403.

16. Klein, A.E.A. (1977). A study of heavy metals in Lake Abaya, Ethiopia, and the incidence of nonparasitic elephantiasis. Water Research 11:323325.

17. Ministry of Agriculture, Food and Fisheries (MAFF) (1995). Monitoring and surveillance of nonradioactive contaminants in the aquatic environment and activities regulating the disposal of wastes at sea. Aquatic environment monitoring report No. 44. Directorate of fisheries research, Lowestoft.

18. Makin, M.J., Kingham, T.J., Waddanns, A.E., Birchall, C.H. and Tamene, T. (1975). Development Prospects in the Southern Rift Valley, Ethiopia. Land Resource Study 21, Vols. 1\&2, Land Resources Division, Ministry of Overseas Development, England.

19. Schroder, R. (1984). An attempt to estimate the fish stock and sustainable yield of Lake Ziway and Lake Abaya, Ethiopian Rift Valley. Arch. Hydrobiol. Suppl. bd. 69:411-441.

20. Talling, J.F. and Talling, I.B. (1965). The chemical composition of African Lake Waters. Int. Revue. Ges. Hydrobiol. 50:421-463.

21. Tamiru Alemayehu (2000). Water pollution by natural inorganic chemicals in the central part of the main Ethiopian Rift. SINET: Ethiop. J. Sci. 23(2):197-214.

22. Telford, R.J. (1998). Diatom stratigraphies of Lakes Awassa and Tilo, Ethiopia: Holocene Records of Groundwater Variability and Climate Change, Ph.D. Thesis, University of Wales.

23. Tenalem Ayenew (1998). The Hydrobiological System of the Lake District Basin, Central Main Ethiopian Rift, International Institute for Aerospace Survey and Earth Sciences. Ph.D. Thesis, ITC Publication No. 64, pp. 9-10.

24. Van Loon, J.C. (1985). Selected Methods of Trace Metal Analysis: Biological and Environmental Samples. John Wiley \& Sons, New York, pp. 1155.

25. Von Damm, K.L. and Edmond, J.M. (1984). Reverse weathering in the closed-basin lakes of the Ethiopian Rift. Am. J. Sci. 284:835-862.

26. Windom, H., Stickney, R., Smith, R., White, D. and Taylor, F. (1973). Arsenic, cadmium, copper, mercury and zinc in some species of North Atlantic Finfish. J. Fisheries Research Board of Canada. 30:275-279. 
27. Yamazaki, M., Tanizaki, Y. and Shimokawa, T. (1996). Silver and other trace elements in a freshwater fish, Carasius Auratus Langsdorfii, from the Asakawa River in Tokyo, Japan. Environ. Pollut. 94(1):83-90.

28. Zauke, G.P., Savinov, V.M., Ritterhoff, J. and Savinova, T. (1999). Heavy metals in fish from the Barents Sea. Sci. Total Environ. 227:161-173.
29. Zinabu Gebre Mariam and Elias Dadebo (1989). Water resources and fisheries management in the Ethiopian Rift Valley Lakes. SINET: Ethiop. J. Sci. 12(2):95-109. 